Mukaddime, 2019, 10(2), 561-581

DOI: $10.19059 /$ mukaddime.581028

\title{
Spatial Concentration of Syrian Immigrants in Spatial Dynamics and Ethnocultural Context
}

Celal Ince

\begin{abstract}
This study examines the spatial dynamics of spatial concentration and the migration process of Syrian immigrants from the perspective of Sanlıurfa province of Turkey. Syrians migrated to Turkey as a result of the civil war that started in 2011. There has been an increase in the number of international immigrants in the world and this continues to be a major issue. On the other hand, immigrants concentrate in certain countries of the world, certain cities of the countries and certain regions of the cities. Syrian immigrants have mostly moved towards Turkey among the neighbouring countries. In Turkey, Şanlıurfa is one of the cities where Syrian immigrants are concentrated. While there are almost no Syrian immigrants in some cities of Turkey, there are more than half a million Syrian immigrants living in Şanlıurfa. This study investigates why Syrian immigrants are more concentrated in Şanlıurfa in terms of spatial dynamics. As a result of interviews and observations made with the immigrants and the field actors who have close contact with migrants, the issue was tried to be analysed. In this context, a total of 76 people including immigrants and field actors were interviewed. As a result of the study, it was observed that the border sociology; historical, kinship and tribal relations between target and source settlements; collective memory and social (ethnic, linguistic, cultural) similarities and the social texture of the target settlement were the determining factors in the concentration of Syrian immigrants in Şanlıurfa and in the immigration process.
\end{abstract}

Keywords: Syrian immigration, Immigration, Turkey, Şanlıurfa

\footnotetext{
${ }^{1}$ Dr. Öğr. Üyesi, Bitlis Eren Üniversitesi, Fen Edebiyat Fakültesi Sosyoloji Bölümü, celalince548@gmail.com,
} ORCID No: https://orcid.org/0000-0001-6081-4100. 


\title{
Etno-kültürel ve Mekânsal Dinamikler Bağlamında Suriyeli Göçmenlerin Mekânsal Yoğunlaşması
}

\begin{abstract}
Öz:Bu çalışma; Türkiye'nin Şanlıurfa ili özelinde Suriyeli göçmenlerin mekânsal yoğunlaşma pratiklerini yerel unsurlara odaklanarak incelemeye çalışmaktadır. Suriye'de 2011 yılında başlayan iç çatışma sonucu Suriye'den Türkiye'ye yoğun bir göç süreci başladı. Dünyadaki uluslararası göçmen sayısı artmaya ve özellikle zorunlu göç bir sorun olarak tartışılmaya devam edilmektedir. Diğer taraftan göçmenler dünyanın belli ülkelerine, ülkelerin belli kentlerine ve kentlerin de belli bölgelerine yoğunlaşmaktadır. Suriyeli göçmenlerin çoğu da Türkiye'nin sınır kentlerine yöneldi. Şanlıurfa, Suriyeli göçmenlerin yoğunlaştığı sınır kentlerin başında gelmektedir. Türkiye'nin bazı kentlerinde Suriyeli göçmen sayısı yok denecek kadar azken Şanlıurfa'da yaklaşık yarım milyon göçmen ikamet etmektedir. Bu çalışma, bu yoğunlaşmanın mekânsal dinamiklerini sorgulamaktadır. Göçmenler ve göçmenlerle yakın temas kuran saha aktörleri ile yapılan görüşmeler ve gözlemler sonucunda konu etraflıca analiz edilmeye çalışıldı. Bu kapsamda göçmen ve saha aktörleri olmak üzere toplam 76 kişi ile mülakat gerçekleştirildi. Araştırma sonucunda sınır sosyolojisinin; hedef ve kaynak yerleșimler arasındaki tarihsel, akrabalık ve aşiret ilişkileri; kolektif hafıza ve toplumsal (dilsel, etnik, kültürel) benzerlikler ve hedef yerleşimin sosyal dokusu, Suriyeli göçmenlerin Şanlıurfa'daki yoğunlaşmasında ve göç sürecinde belirleyici faktörler arasında yer aldığı görüldü.
\end{abstract}

Anahtar Kelimeler: Suriyeli göçmenler, göçmenler, Türkiye, Şanlıurfa

\section{Introduction}

Along with the reflection of the process described as the "Arab Spring" in Syria, in 2011, demonstrations against the regime started by the people in Syria., evolved into a civil war in a short period of time (Dalar, 2016). Immediately triggered a mass influx from Syria to other countries. Syrian immigrants took refuge in neighbouring countries and mostly in Turkey. A significant proportion of international immigrants concentrate in certain parts of the world and undergoes spatial segregation in the countries they go (Murdie, \& Borgegard, 1998). On the spatial concentration of the international immigrants at the country level, in general, the welfare level of the target country, the historical and social relations between the target and source countries, family ties and linguistic similarities are decisive (Bloch, 2002).

Even after immigrants migrate to the target country, they are not distributed in a balanced manner to all of the provinces of the target country but move towards certain provinces and certain locations. Syrian immigrants in Turkey, too, move towards certain provinces in Turkey. Among the most important of these provinces is Şanlıurfa where 515648 Syrian immigrants live. In this context, when Syrian immigrants in Şanlıurfa are compared with Syrian 
immigrants living in other provinces, it is possible to talk about a Syrian immigrant concentration at the provincial level ${ }^{2}$. If a particular group has a high level of representation in one region or has a high proportion of the population, there is spatial concentration (Van Kempen \& Özüekren, 1998).

The fact that Sanlıurfa and some settlements of Syria (Rakka, Aleppo) used to be connected under the Ottoman administrative structure, that these cities are in the same geographical basin of Al-Jazeera, and that the pre-existing mutual social relations led Syrian immigrants to prefer Şanlıurfa more. Historical relations, collective memory, kinship and tribal ties, faith and cultural resemblance built on the dynamics mentioned above, lead to a spatial concentration. These factors also enabled a smoother immigration process to take place compared to the migration of Syrian immigrants to other regions (Kaya, 2017). There are many similarities between Şanlıurfa and certain Syrian cities. This similarity prevents Syrian immigrants from being exposed to 'cultural shock' (Bates, 2009). Moreover, the similarity of social structure between target and source settlements eliminates many unknowns that immigrants face frequently.

Although almost all Syrian immigrants were concentrated in the border provinces during the first phase of migration, the continuation of civil war in Syria caused immigrants to move towards the western and especially bigger provinces of Turkey. Cities such as Istanbul, Bursa and Izmir are among the leading cities where Syrian immigrants headed. Work opportunities are at the core of the migration to these cities. However, more than two-thirds of Syrian immigrants in Turkey continue to reside in the Syrian border provinces of Turkey. Şanlıurfa has an important place among these provinces as the host of 515648 million Syrian immigrants. ${ }^{3}$

It is estimated that the historical relations between Şanlıurfa and Syrian' cities, as well as the opportunities Şanlıurfa offers to Syrian immigrants will be influential in the continuation of migration traffic and determining spatial concentration. As a result, although Syrian immigrants have migrated due to compelling reasons, the target settlements are the places that met their needs. The nature and extent of needs vary based on time and place. What opportunities does Şanlıurfa offer Syrian immigrants, and what characteristics of Şanlıurfa lead to spatial concentration of Syrian immigrants? In the following section, we will investigate these questions? Using interviews with 76 people, including Syrian immigrants and local actors who have close contact with them in Şanlıurfa in 2017. In fact, these interviews were conducted for the "Spitial Sociology of Immigration: The Example of Şanlıurfa" study (Ince, 2018). However, data not used in the aforementioned study were used in this article.

\footnotetext{
${ }^{2}$ For a detailed see, http://www.goc.gov.tr/icerik6/gecici-koruma 363_378_4713_icerik, Date of access: 04.09.2018; Şanlıurfa il Göç Idaresi, 05.02.2018

${ }^{3}$ Şanlıurfa il Göç İdaresi, 05.02.2018. The local administrative department on migration.
} 
Sample obtains an ethnic diversity (Arab, Kurdish, Turkish) and gender balance. The sample consisted of 56 Syrian migrants and 20 NGOs. The ages of the migrants interviewed ranged from 18 to 80 years. Interviews were held in different places such as housing, school and office. Pseudonyms are used instead of real names.

\section{Cultural Coexistence with Historical and Collective Memory}

The social structure and historical and collective memory are among the decisive factors in the concentration of Syrian immigrants in Şanlıurfa, as well as in the regeneration of social relations. One of the main objects of history, as reported by Halbwachs (1992), is to bridge between the past and present and to reconstruct the time to time interrupted continuum. In this context, Şanlıurfa, which dates to the Neolithic period, is one of the oldest cities in the world according to the archaeological findings. The oldest temple in the world is located in Şanlıurfa ${ }^{4}$. Sumerian, Akkadian, Hittites, Babylonians, Kalde, Hurrians, Mitanni, Aram, Med, and Persian States ruled the Şanlıurfa region in different centuries. Similarly, Macedonian, Roman, and Byzantine civilizations were influential, followed by the Seljuks, Eyyubi, Mamluk, Turkmen tribes, Timurid Empire, Akkoyunlu, Dulkadirs, and Safavids. In addition to hosting many states and civilizations, Şanlıurfa was the place where many prophets lived. In this context, religious references in social analysis in this region present important findings (Kaya, 2004). As a matter of fact, ansar and muhajirun ${ }^{5}$ (the helpers and the migrants) rhetoric has become one of the most frequently used themes in Şanlıurfa in reference to Syrians' migration. This theme has become even more important for Syrian immigrants who do not have social networks and kinship relationships (Kaya, 2017).

As stated in (Barth, 1998), many ethnic groups come together and form a social structure for living together. Different states that ruled the region, hosting many Abrahamic religions, and the coexistence of many ethnic groups have led to the emergence of a multi-cultural social structure of living together. While Syrian immigrants migrating to other provinces of Turkey face discrimination, this situation is felt less so in Şanlıurfa. According to a study (Kaynak et al., 2016), $82.8 \%$ of the Syrian immigrants included in the sample indicated that the people of Şanlıurfa had a normal and positive approach towards them, while 17.1\% Syrian immigrants perceived negative approach. Syrian immigrants and field experts summed this up as follows:

"The people of Şanlıurfa are generally poor, they are not complex, they look after the Syrians (Haşim, Syrian immigrant).

\footnotetext{
${ }^{4}$ Türkiye İstatistik Kurumu (Turkish Statistical Institute), "Seçilmiş Göstergelerle Şanlıurfa", Date of access: 07.09.2015, http://www.tuik.gov.tr

${ }^{5}$ The Muslims who had to migrate from Mecca to Medina in Islamic history are called muhajirun, and the Medina people who accepted them as brothers are called ansar.
} 
I've been in Urfa for over six years. I never felt foreign, if I felt foreign, I would return to Syria. The country is the same; Arabic and Kurdish are spoken (Fahri, Syrian immigrant).

Şanlıurfa is good, there are people who understand our language. We did not see any harm from the people here. I hope the war will end in our country and we will return home (Gülsüm, Syrian immigrant).

I like morals of Urfa, they don't show us hostility. It is better than other places. Neighbours are good. They are religious people. When the people are like this, we are not afraid or worried. Of course, we don't behave in a way that disturbs the neighbours or the society (Hamza, Syrian immigrant).

The people of Şanlıurfa take care of the Arabs. That's why Syrians come to Şanlıurfa more (Abdullah, Syrian immigrant).

Here, Syrians feel the least of the affliction and misery of coming from another country. This is the city where you feel least rejected. People here don't tell them to go away. If they say that is because of economic reasons (Field expert)."

The fact that Syria remained under the rule of many states in history and played an important role in the spread of many religions created diversity in terms of ethnicity, religion, and sect (Çelikkol, 2015). Şanlıurfa's similar cultural pluralism makes it easier for Syrian immigrants to live there. Ethnic diversity leads to conflicts on one side, while on the other, provides important opportunities for the individual. A field expert says:

"Şanlıurfa has a culture of living together. This culture comes from the Ottomans. Many ethnic groups can live together without any problems. There is a culture of acceptance. There are Arabs, Kurds, Turks in Şanlıurfa. Syrians are not accepted when they go to another place. Because the cultures are different. But people from Şanlıurfa and Syrians are people of the same culture (Field expert, AFAD)."

Şanlıurfa's ethnic pluralism gives the city an opportunity for Syrian immigrants from different ethnic groups to find meaning in their lives. According to Barth (1998), common culture is one of the main characteristics of ethnic groups and is a product of ethnic group formation.

\section{Common History, Common Geography and the Elements of Cooperation}

During the Ottoman period, some settlements in Şanlıurfa and presentday Syria were connected to each other. Şanlıurfa was a sanjak under the Ottoman rule, an administrative district of a province (Rakka, Aleppo) that is now in Syria, or a sanjak to which an administrative district (Rakka) was 
connected. Hence, this common administrative structure and historical relations were decisive in the construction of common social relations. During the Ottoman period, 'common cultural and kinship ties' developed between the peoples of Turkey-Syria border regions for four centuries (Kaya, 2017). This common social structure has helped having a smooth migration process (Ince, 2019). The collapse of the Ottoman Empire and the political border drawn between Syria and Turkey divided ethnic groups, relatives, and tribal ties. However, although these relatives grew differences over time, they carried traces of a collective memory in many ways from lifestyle to architecture from funerals to culinary culture (Kaya, 2015). Syrian immigrants expressed their thoughts about the common history as follows:

"I came from Aleppo city of Syria. I am the grandson of Ibrahim Pasha, the leader of the Kurdish National tribe. I, my father, my grandfather, my grandfather's grandfather have been a citizen here for 600 years (Mirvan, Syrian immigrant).

My birthplace is Sarekani, but I have lived in Damascus for many years. Some part of our tribe is Kurdish and some is Arab. Our descendants migrated from Diyarbakır to Syria (Serhat, Syrian immigrant)."

Along with historical relations, geographical tie has also been decisive in the formation of kinship ties, tribal ties, cultural transitions, and a collective memory between Şanlıurfa and Syria's cities. As reported by Barth (1998), while the same ethnic group living in different geographical regions can develop different forms of social behaviour, it is more likely that the same ethnic group living in similar geographical regions have common cultural codes of conduct. McDowall (1996) added that while blood ties constitute a component of tribal ties, territorial ties constitutes the other main component. Leach (2003) states that the soil and the people who are integrated with it are in the same ontological state and that the soil and people are living and alike.

Some settlements in Şanlıurfa and Syria are located in the same geographical basin known as Al Jazeera. Therefore, especially the geography on both sides of the border where Kurds live, "landforms, climate, and vegetation are exactly the same." Geographical ties were decisive in the formation of a collective memory and a similar culture among the cities of Syria and Şanlıurfa. According to Halbwachs (1992), collective memory is embodied in place and objects. He adds that there is a very strong connection between habits, the mind of a group, and the appearance of the places inhabited. Similar to geographic ties, kinship relations also provide the development of a sense of collective identity (Bates, 2009).

As a matter of fact, some authors explain the kinship relations as follows. According to Sahlins (2013), the common existence between relatives decreases 
or increases proportionately with spatially and genealogically calculated distance. Ibn Khaldun (2004) argues that the level of strength of the common past image of community members is directly proportional to the level of solidarity they exhibit. The spatial and genealogical proximity between Şanlıurfa and the Syrian people also increases the degree of their co-existence. The common relations developed during the historical process are a functional factor in the migration process from Syria to the province of Şanlıurfa, the regeneration of social relations, and the re-existence of immigrants.

The most important element separating society from individual people is the collective identity that connects all individuals and gives them a common feeling, consciousness and spirit (Kaya, 2017). Khaldun describes this collective spirit or identity with the concept of group feeling. The concept of nobility, which is given a multi-dimensional meaning by Khaldun, refers to a person's tribal feelings and efforts that protect and support one's relative or one of his or her own tribe against all others in all matters without considering whether he/she is right or wrong. Khaldun believed the fact that someone who is persecuted or confronted with a catastrophe calling his/her relatives to help is the result of this bond (2004). Emile Durkheim, on the other hand, explains the element of solidarity with collective consciousness. Durkheim (2018) states that in the average of the members of a society, all living beliefs and emotions form a certain system that has a unique life. This is the collective consciousness.

\section{Migration of Syrians to Şanlıurfa}

Syria and Turkey are two separate nation-states that emerged as a result of the collapse of the Ottoman State. The area where these two separate nationstates emerged had a pluralistic structure during the Ottoman period. Especially both sides of the border where Şanlıurfa was located had many common ethnic, tribal, social, and cultural elements during the Ottoman period. The administrative relationship between Şanlıurfa and Syria's settlements ended when the political border between Syria and Turkey was drawn based on the Treaty of Lausanne. In this context, along with the Treaty of Lausanne, not only the geographical division took place and two separate nation states emerged, but also the social groups and relations were divided, where a pluralistic structure prevailed (Kaya, 2017). So, what is a border and what does it mean?

Border-drawing processes regulate the passage of humans, animals and commodities in ways that support or impede their movements. Border is a tangible phenomenon that separates, that can be opened or closed. In this context, border can be considered as a physical line that separates a nation, culture, and people from a different nation, culture, and people. In recent history, especially after World War I, when the international borders were drawn, human relations were not taken into account or were even ignored. The borders did not function as elements that separated different cultures and 
peoples, but as elements that divided the same culture and people, separating people, tribes, communities, villages, and relatives (Özgen, 2005).

Unlike the pre-modern period, in the nation-state process, borders were shaped not according to social relations, but according to the wishes of the sovereign states. For example, the new boundaries drawn as if cut with a knife, have broken the social, historical, religious, ethnic, geographical, architectural and environmental textures that have been around for centuries into different pieces. Şanlıurfa Syrian border region was also not homogeneous in terms of the tribal structure. In the Suruç region, tribes of Berazi, Şeddadi, Didan, Asi, Şeyhi and Pijan, and some of the Beni Icıl, Beni Ciburi tribes in Akçakale region remained on the side of Şanlıurfa while the border was drawn and the other part remained on the other side of the Syrian border (Kaya, 2017). Although there was a deep break in the social relations between relatives, tribes, and members of the same ethnic group on both sides of the border, the mutual social relations between Şanlıurfa and Syrian' cities continued until today. Kinship relations and tribal relations, which had previously been built in a common place, in a sense of belonging to a group, then continued in various forms. As the Syrian immigrants say:

"We have many relatives in Urfa. They used to come to us all the time before the war, and ours used to come here. There are also a lot of relatives from Syria here (Ayşe, Syrian immigrant)."

According to Şenoğuz (2014), even though states create separations by drawing borders, those living at the border manipulate these divisions through social networks and links on the border. Moreover, if there is a cultural difference between communities on both sides of the border, it increases the border effect. However, if there is an ethnic, linguistic, religious and socioeconomic similarity among the communities on the border, the reciprocal relations challenge the border and undermine its the legal function (Brunet-Jailly \& Dupeyron, 2007). For instance, trade activities at different levels between Turkey and Syria, particularly in Şanlıurfa region has never stopped, despite the harsh security measures at the border between the relatives, tribes and cultures. The movement between the two sides continued until today, with ups and downs based on political conditions. During Sheikh Said Rebellion, many people migrated from Turkey to Syria and took refuge with their relatives. At other times, many people emigrated from Turkey to Syria. As the Syrian immigrant says:

"My mother went to Syria as a bride. My mother is from Şanlıurfa and a citizen of Turkey. That's why we came to Şanlıurfa. We came here because our relatives and acquaintances are here. We do not suffer many of the difficulties of being a foreigner here, city is like ours; there are relatives (Kasım, Syrian immigrant)." 
The making of national political border, does not and could not prevent the historical relations between Şanlıurfa and Syria. Although the wire fence built and the mines laid hindered the passage, the mutual trade and marriages continued. So much so that until recently, "Aleppo yarn", "Aleppo Broom" was famous in Şanlıurfa and sold a lot. Those who were born and raised in Şanlıurfa definitely heard one of the cities of Aleppo, Damascus, and Rakka before they migrated to Syria (Kurtoğlu, 2016). The sociological ties/bonds, which was formed by the ties of common religion, history and culture in the past continued to exist in a variety of ways until today. Even before the civil war, many Syrians were migrating to Şanlıurfa. Later, immigrants who migrated to Şanlıurfa also expressed their familiarity with Şanlıurfa with these words:

"The reason why there are many Syrian people in Şanlıurfa is that Şanliurfa is very close to Syria, and they are very similar to each other. We do not feel like a foreigner here. Most of our customs are the same, the way we wear is very similar. We feel like we are in Syria. We meet with our friends and relatives all the time. I can also do here what I did in Syria. Just, I can't go to school. And it is very good for us that Şanlıurfa is Arab. Because we can easily ask something we do not know or a place. I've lived in other cities too, and this is not the case in other cities. If you don't know Turkish, you're having a lot of trouble (Lokman, Syrian immigrant)."

Despite all the obstacles, although there were periods of decline and increase, many products were transferred from Syria to Şanliurfa and from Şanlıurfa to Syria through "smuggling" (Öğüt, 2011). The perception of space, history, and geography rooted in the past and common memory helped continue these relations. Through social institutions, social structures, memory, oral culture and tactics and practices produced in everyday life, these relations have come to the present, despite partial break offs. This common past, cultural similarity and the continuation of kinship relations to the present day were important factors in the concentration of Syrian immigrants in Şanlıurfa and have led to a smooth transition. As the field expert says:

"What I observe is that the kinship relationship played an important role in this process. In Ceylanpınar, in Suruç, in the city center, the relatives on this side took care of their relatives from the other side; they took their relatives right beside them immediately, tried to find and generate solutions (Field expert)."

Syrian citizens who had been part of the Ottoman Empire in the past migrated to Turkey, the other part of the Ottoman Empire, and in particular to Şanlıurfa, next to their relatives and acquaintances. Although Syrian immigrants were mostly concentrated in Şanlıurfa in Turkey, especially in the first period, the trade and kinship relations, ongoing trade and kinship relations before the war, 
cultural similarities and lifestyle were effective in ensuring a smoother transition compared to other provinces.

\section{Protected Islands: Kinship Relations, Tribal Ties and Social Networks}

According to Barth (1998), history has created peoples socially and culturally different from one another, and these peoples are like islands, isolated within themselves. In his study, Collective Memory (1992), Halbwachs says that from time to time, to discover the protected islets of the past as they are, it is necessary to go quite far. With the drawing of the Turkish-Syrian border around 90 years ago, kinship and tribal ties were also divided along with the geography. These kinship and tribal ties became the protected islands expected to be discovered, as Halbwachs said, in the concentration of Syrian immigrants in Şanlıurfa and in the migration process. In addition, only kinship relations and tribal ties were not influential in Syrian immigrants heading to Şanlıurfa. Social networks, which include the elements mentioned and which offer a wider range of resources were also decisive.

In the Şanlıurfa region, kinship relations, tribal ties and social networks between the peoples on both sides of the border are decisive for Syrian immigrants to concentrate in Şanlıurfa, moreover, to concentrate in certain parts of the province and to regenerate social relations. In this context, it is useful to mention briefly what kinship relations and tribal ties are and through what practices they took part in the process of solidarity and helping each other. Later, we will proceed to the practices of solidarity and cooperation that the kinship relations and tribal ties have provided to the immigrants during and after the Syrian migration process.

According to Stasch (2009), referring to the relation among subjects, the relative-the other is the person's own attribution. One recognizes the other as himself/herself and embraces the other as an object peculiar to his/her own existence. A concept that is closely related to the concept of kinship is tribe. Tribe, derived from the word 'Ashira' and a concept of Arabic origin, refers to the broad family communities in general, even though there are many other meanings. Tribe is also defined as a socio-political unit, which has a peculiar internal structure, usually a territorial unity organized on the basis of kinship that is real or assumed to be real and a common land (Bozkurt, 2003). Sahlins (2013), the members of the group, formed as a whole in traditionally discrete entities were united on the basis of common ancestors, common settlement, common nutrition, common land use or other common reciprocal means. In this context, they are equal and their relationship is defined by unconditional friendship.

According to Khaldun's (2004) statement, kinship relations based on real or 'imaginary' faith and tribal relations are important elements that provide unity and solidarity among people. Sahlins (2013) states that the social manifestation of togetherness is that if one is injured, others suffer too. According to him, even 
if the person injured himself/herself, this situation may require that the relatives of the injured person suffer equally. As a result, kinship relations provide basic support and solidarity (Ökten, 2006).

Tribal ties and kinship relations were present between Şanlıurfa and Syria before the migration process. Members of many tribes and their relatives lived in different parts of Syria, such as Aleppo, İdlip, Kobani, Rakka, Kamışı, Haseke, and they maintained a collective memory. Collective memory is a pattern of similarities; it convinces itself that the group remains the same, and focuses its attention on the group (Halbwachs, 1992). In Şanlıurfa region where tribal ties continue to be important despite the modernization practices, kinship offers social solidarity and a broad coherence system surrounding the individuals (Ökten, 2009). As a matter of fact, one of the basic principles of the tribal tradition is the intra-group solidarity (Ökten, 2006). A significant part of the immigrants to Şanlıurfa also stayed with their relatives especially in the first period of the Syrian immigration, and some still stay with their relatives. The existence of kinship relations and tribal ties on two sides of the border in the Şanlıurfa region provide a social reserve for the Syrian immigrants. Just as the Syrian immigrants interviewed say:

"My uncle is from here (Şanlıurfa). When we first arrived, my uncle temporarily gave us one of his houses and we lived there for 6-7 months. Then I rented a house; my father and my brothers went to work. Now I stay with my wife and children. (Murat).

When we first arrived, we stayed in our relatives. I was going to go to Saudi Arabia but it didn't happen, so we rented a house (Sadık, Syrian immigrant)."

Tribal ties, kinship relations, and collective memory in the Şanlıurfa region, where traditional relations dominate, are the determining factors for Syrian immigrants to concentrate in Şanlıurfa and to experience a smooth transition by forming a solidarity element. Kinship relations and tribal ties provide assistance and solidarity practices in the migration process of Syrian immigrants, as well as important service resources after migration. These elements prevent Syrian immigrants from being exposed to alienation.

"And we have close relatives here. We do not feel ourselves as foreigners here. It doesn't make much difference, we're not strangers here, we have friends (Nuri, Syrian immigrant)."

Durkheim (2018) took the view that there is a social structure of a certain quality, to which mechanical solidarity is appropriate. The introductory feature of this social structure creates a system composed of pieces that are alike and similar to each other. According to Taştan (2010), although modernization destroys mechanical solidarity or community structure, the core element that constitutes the essence of society continues its existence as in the Syrian 
migration process. A significant number of Syrian immigrants in Şanlıurfa, try to make life easier by supporting each other on many issues. As the Syrian immigrant interviewed expressed:

"We have some of our relatives in Şanlıurfa, some in Gaziantep. We see each other often. So when we have a deficiency, we ask from them, and when they ask for help, we help them. We help both when it comes to money and when there is a job opportunity. For example, when I find a job and an extra employee is need, I call one of my acquaintances (Abdullah, Syrian immigrant)."

An important theory explaining the process of migration, the process, settlement, and spatial concentration is social networks. In the context of migration, social networks are a concept that refers to interpersonal connections, such as the country from which immigrants come, the country where they settle, the old immigrants, the new immigrants and the common roots, fellow citizenship, kinship, and friendship. In other words, migrant networks are a series of interpersonal ties that connect migrants, ex-migrants and non-emigrants through kinship relations, friendship and root of the community (Palloni, et al., 2001). Immigrants act within the social and cultural networks they have. They determine their migration routes based on the information given by their relatives and friends who migrated before them. As the Syrian immigrants interviewed say:

"There were clashes between YPG and FSA. We were left amidst the clashes, then we came to Sanlıurfa. First we came to Harran, a nephew found a job for me there. My nephews had come before us (Asiye, Syrian immigrant).

I came here two years ago, my brother and uncle had come before. They had come four months before me, my aunt had already come. Then I came here (Ridvan, Syrian immigrant)."

Social networks have many important functions, from migration process to employment process. In other words, social networks influence the economic and social lives of immigrants, thus determining their spatial preferences. Social networks that the individual possesses ensure mutual assistance when finding employment and facing difficult situations (Bloch, 2002). Immigrant networks, along with the mobilization of various social capital such as kinship, tribal, ethnic, and religious ties alleviate the social and economic troubles of immigrants. It is effective in adapting to the new way of life and meeting their basic needs. Relationship networks allow immigrants not to experience the feeling of being lonely not only in the economic sense, but also in the social sense (Crisp, 1999). Immigrants benefit from social relations networks and solidarity patterns while struggling with many problems. As the Syrian immigrant tells: 
"We came to Urfa. The reason we come to Urfa is because Urfa is close to us. We understand their language and have relatives here (Ayşe, Syrian immigrant).

When we found a house, when we went to work together, our relatives helped (Sahra, Syrian immigrant)

We came to Urfa because my father's uncle was in Urfa and because it was close (Sahara)."

The social networks that the Syrian immigrants have, with a continuous expansion, provide them with convenience in many matters, including material and social issues. Through the networks established, Syrian immigrants, who are aware of each other, are concentrated in certain places and provide support to each other. Because migration networks provide migrants not only with readymade migrant routes, but also with migrant networks, employment opportunities, financial and cultural accumulation, and also offers the opportunity to socialize within the settlement and immigrant community. In addition, workplaces, associations, coffee shops, restaurants, attorney's offices, doctors' offices, shops, etc. immigrants have established, meet the economic and especially the cultural needs of the newcomers (Baklacıoğlu, 2010).

\section{Having Similar Ethnicity, Language, Religion and Culture}

In the literature, settlement process of immigrants is explained around four main subjects. These include the political system of the host society, the social networks that immigrants have, the individual qualities of migrants, and migration conditions (Bloch, 2002). In addition to the state's immigration policy and immigration conditions, the networks and qualifications of the migrants determine which country or city the migrants are going to head to. Ethnicity, religion, and culture that immigrants have come to the forefront. When groups with different ethnic, religious and cultural backgrounds start living together, it is possible to have many problems at individual and social levels. Yet, having a similar ethnicity, religion and culture may provide a variety of conveniences. Having similar ethnicity makes it easier to cope with the demands and obstacles of life as a result of social positions and encounters (Eriksen, 2002). Indeed, the common language indicates that the motivation for taking care was strong (Fenton, 1999). Syrian immigrants interviewed explained the similarities between Şanlıurfa and Syria's settlements as follows:

“Deyrezzor, Rakka and Haseke and Şanlıurfa are the same. Language is the same, culture is the same, lifestyle is the same (Naci, Syrian immigrant).

According to Keser (2008), ethnicity and religious differences are associated with political processes in studies conducted in Turkey because of their 'different cultural characteristics' and are 
considered as the main actors of the political conflict. This study focuses on the solidarity function of similar ethnicity, religion and culture. The social distance between Şanlıurfa and Syria's borders to Şanlıurfa are low and the similarity of lifestyle are influential in directing Syrian immigrants to Şanlıurfa. As the Syrian immigrants and field experts say:

Cultural familiarity is a factor, for example, although there is not much difference between Maraş and Aleppo as a place and they are not far from each other, there is a lot of cultural difference between them or Malatya or Adiyaman. There is a cultural difference between Malatya and Aleppo, or Telebyad. But between Urfa and Aleppo, Rakka and Haseki, there is no big difference in culture. Clothing, style, eating and drinking etc. (Field Expert, Charity Organization).

We live in Şanlıurfa's Eyyüpkent neighborhood. There are a lot of Arabs from Şanlıurfa and many Syrians. We feel comfortable there (Salih, Syrian immigrant).

Most Arabs here are closer to us. We do not feel like a stranger. We understand each other (Hatice, Syrian immigrant)."

In Simpson's work (2017), it was seen that choosing places with similar ethnic and familial characteristics was an informal strategy employed by immigrants to reduce the cost of migration and settlement. Immigrants emphasize the various identities they have, according to where they migrated and the ones that will help them relate to the society they are in. Which features are to be highlighted or which ones to be suppressed are determined based on the national circumstances of the settled country, the local histories of the groups and their socio-cultural characteristics (Danış, 2010). There is no doubt that the identity elements that one possesses is ethnicity (language), religion, and culture. As these elements might be sources of conflict, they can create a social capital resource when there is a new wave of migration.

"Life in Şanlıurfa is easier and closer to our culture. Languages are the same. Arabic is spoken a lot. So we can communicate comfortably. We can shop. Şanlıurfa is a beautiful city. We are similar in many ways. The dresses are the same (Gülsüm, Syrian immigrant).

...because those who do not know Turkish do not have a communication problem in Şanlıurfa. There are Arabs, Kurds. The rentals here are cheap. Somehow, we make a living (Rukiye, Syrian immigrant)."

Ethnicity, religion and cultural similarities form the background of solidarity, a fundamental component of social capital that facilitates access to many services in the life of an individual. Solidarity serves the development of 
social capital between individuals and communities, depending on their trust, familiarity, values, and relationship patterns (Carpiano, 2006). Immigrants, especially those who come with a chain migration method continue their cooperation and solidarity relationships as they come from similar environmental settlements and kinship relations. It is also possible to encounter this practice in the lives of Syrian immigrants:

"Most of our relatives came to Şanlıurfa after us. Half of our relatives live in Hayati Harrani, Eyüpkent, others are in Yenişehir, Bamyasuyu, Bahçelievler (Şemse, Syrian immigrant).

Most of our relatives in Syria came to Urfa. We support each other in all kinds of matters. When renting a house or looking for a job, we consult each other. We visit each other often (Hatice, Syrian immigrant).

Some of our friends had come here before us. They said that people are good, it is a safe place and we came (Hamza, Syrian immigrant).

Our relatives had already come to Urfa and we also came to Urfa. And Urfa is close to us (Hafsa, Syrian immigrant)."

In Coleman's view (1990), strong social relationships based on solidarity and trust in the context of social closeness are social capitals that help achieve individual goals more easily. The group or individuals having a similar ethnicity, belief, and culture improve their social capital by acting in solidarity and making it easier to adapt. Immigrants use these elements when struggling with many problems. Social networks and solidarity patterns provide opportunities for them. Language, culture, and ethnic similarity are also the determining factors in creating a privileged situation in reaching markets and resources. Moreover, the same group membership of any two people requires that the same game be played between these two people, and the actions that these two people exhibit in different areas of social life can intersect (Barth, 1998). The Syrian immigrants in Şanlıurfa are a good example of this:

"Şanlıurfa is no stranger to us. When I compare with other provinces in Turkey, Şanlıurfa is a more religious city. I've been here a long time. I have not had a problem other than economic problems. Our religion is the same, our language is the same (Hafsa, Syrian immigrant)."

A study conducted in Europe ${ }^{6}$ supports this idea. The research asked participants to evaluate asylum seekers and refugees in various categories. A significant proportion of the participants stated that they wanted asylum

\footnotetext{
${ }^{6}$ https://www.welt.de/politik/deutschland/article158319248/Europaeer-wollen-keine-Muslime-alsAsylbewerber.html, Date of access : 23.09.2016
} 
seekers and refugees to be young, educated, and preferred Christians both to agnostics and to Muslims. In this context, migration, in a certain sense, is a matter of social acceptance. While immigrants choose a country and area of settlement they take these elements into account, and prefer regions where social distance is low, if possible. As the Syrian immigrants put it:

"I do not want to go to another country, this is an Islamic state. We have many similar aspects. Here, we can understand each other more or less, our customs are alike (Osman, Syrian immigrant).

Turkey is a Muslim country. There are also other Muslim countries, but the one that understands us best and takes care of us is Turkey (Hamza, Syrian immigrant).

Turkey is culturally closer to us. The language is the same. Coming here is easy. We did not encounter a problem when coming here (Zümra, Syrian immigrant)."

Social acceptance of Syrian immigrants in Şanluurfa is high despite the problems arising from the historical relations between the Syrian immigrants and the people of Şanlıurfa. According to a study (Kaynak et al., 2016), the proportion of Syrian immigrants who were subjected to alienation in Şanlıurfa was only $2.9 \%$. Some Syrian immigrants have lands, relatives, tribes, and ethnic groups in Şanlıurfa. Therefore, it is not possible to describe the Syrian immigrants in Sanlıurfa as foreigners and they are exposed to the alienation process at a very low level. Ethnic belonging and cultural closeness are the basis for the low reaction of local people to Syrian immigrants in Şanlıurfa, in contrast to many provinces in Turkey. A Syrian immigrant summed up that he felt safe in Şanlıurfa as follows:

"I feel safe all over Şanlıurfa. Since I've been living here for a long time, I feel like I belong here. When I go out of Şanlıurfa, I feel like an outsider (Selman, Syrian immigrant)."

Syrian immigrants who migrate to Şanlıurfa, where traditional religious practices prevail, sometimes benefit from the sources of their religious arguments, sometimes from the sources of the ethnic group they belong to and sometimes using both of the sources, benefit from solidarity networks and develop social capital. The economic situation of immigrants, cultural closeness, language, and religion adopted by immigrants are decisive in the process of a soft or harsh transition. Syrian immigrants expressed this transition period as follows:

"This people here help Syrians because they are Muslims and flee the war (Sadık, Syrian immigrant)."

The cultural similarity between residing population in Şanlıurfa and the Syrian people reduces the alienation as well as the exclusion. It is estimated that 
depending on the similarity of culture, alienation and exclusion of Syrian immigrants increases as you move to the Western provinces of Turkey. According to a study conducted in Izmir (Çetin, 2017), the Syrian immigrants interviewed stated that one of the main problems they face was exclusion. Many similarities in Şanlıurfa facilitate the transition process. As the Syrian immigrants say:

"There is a similarity of language and faith, if we were not Sunni, if we were Alawi, perhaps we would not be welcomed so well. Here you have the Arabs, the Kurds, the Turks, you find a common language. Many settlements in the border regions were previously one piece, and the border divided them into two. Suruç and Kobani are like that, Akçakale and Nusaybin are like that (Kadir, Syrian immigrant).

We ran away from war and starvation. Because there isn't only war in Syria, there is unemployment, there is hunger. My family and I first came to Telebyad, Syria, and stayed there for a year. I looked, there is no house, no work in Telebyad and the war continues. We said we had to rebuild our lives. I decided to come to Şanlıurfa. We came to Şanliurfa because in Urfa, there are many Arabs, at least we can communicate (Mirvan, Syrian immigrant)."

Bates's (2009) view was that cultural practices that determine everyday life are based on stability and continuity. However, this trend of stability and continuity may be interrupted dramatically as a result of a catastrophic war. People who are pulled out of their routine practice and lifestyle face the tension described as "cultural shock". A person, who enters a cultural setting that he/she is not familiar with, feels 'lost'. Syrian immigrants who migrate to Şanlıurfa are not subjected to cultural shock or they experience it at a very low level. They experience the language problem at a very low level as well. Syrian immigrants migrating to Şanlıurfa have either Arab, Kurdish or Turkish or Sunni or Alevi sociological identity. Şanlıurfa also has the same sociological identities. A Syrian immigrant told us how this sociological identity made it unnecessary to learn a new language as follows:

"I can speak Kurdish and Arabic. If I were in another province, maybe I would have to learn Turkish, but there is not much need here (Selman, Syrian immigrant)."

For Bosswick and Heckmann (2006), solidarity-based structures have a very positive function in the short run at the first stage of the migration and integration. Those who first emigrate share important experiences and knowledge with the immigrants coming later. Kinship relations provide important sources of solidarity in this process. 


\section{Conclusion}

National-political boundaries were drawn between Syria and Turkey. However, despite the border, there are strong sociological patterns of ethnic, religious and cultural strength on the borders of the two states. These patterns have been an important value in reducing migration difficulties in post-2011 Syrian migration. The concentration of Syrians who came to Turkey along the borders, and they tell of the interview made immigrants support this idea.

Pull and push factors are decisive on the individual's preference for destination. The social structure of Şanlıurfa, historical and geographical partnership, collective memory, kinship relations, tribal ties, social networks, ethnicity, language, religion, and culture are pull factors for Syrian immigrants concentrating in Şanlıurfa instead of many provinces in Turkey. Exclusion, physical distance, cultural differences, life-sustaining difficulties, and lack of language constitute the push factors that prevent Syrian immigrants from heading towards other provinces of Turkey. In other words, the concentration of Syrian immigrants in Şanlıurfa and the fact that they are faced with a softer immigration process than the others are based on the unique connections between Şanlıurfa and Syrian cities.

Şanlıurfa's historically multicultural social background makes the social acceptance of Syrian immigrants easier. Ethnic, religious, and cultural similarities raise the level of acceptance and bring about a softer immigration process. Şanlıurfa has a religious conservative tradition has led to the frequent emphasis of ansar-muhacir theme in the Syrian migration process. The fact that the people of Şanlıurfa and Syria have a common historical background has caused them to have a collective memory. Common historical memory and many similarities prevent Syrian immigrants from experiencing cultural shock in Şanlıurfa. Kinship, tribal, and ethnic relations between Şanlıurfa and Syrian cities have gained a new form with the Syrian migration. These elements had an important function in the context of providing basic needs for Syrian immigrants, especially in the first phase of migration.

The fact that those migrating from Syria to Şanlıurfa are Arab, Kurdish and Turkish and the presence of the same ethnic groups in Şanlıurfa has almost completely eliminated the language problem frequently encountered by immigrants. The elimination of the language problem facilitated the access of Syrian immigrants to many social services in the city centre. Social relations continuing between Şanlıurfa and Syrian' cities that took place before the civil war have gained a dynamic nature with the migration process. 


\section{References}

Baklacıoğlu, N. Ö. (2010). Dış Politika ve Göç: Yugoslavya'dan Türkiye’ye Göçlerde Arnavutlar (1920-1990). İstanbul: Derin Yayınları.

Barth, F. (1998). Ethnic Groups and Boundaries: The Social Organization of Culture Difference. Waveland Press.

Bates, D. G. (2009). 21. Yüzyılda Kültürel Antropoloji: Insanın Doğadaki Yeri. Çev. Suavi Aydın. İstanbul: İstanbul Bilgi Üniversitesi Yayınları.

Bloch, A. (2002). The Migration and Settlement of Refugees in Britain. Houndmills, Basingstoke: Palgrave Macmillan.

Bosswick, W. \& Heckmann, F. (2006). "Integration of Migrants: Contribution of Local and Regional Authorities." European Foundation for the Improvement of Living and Working Conditions. University of Bamberg, Germany: European Forum for Migration Studies.

Bozkurt, i. (2003). Tarih Boyunca Aşiretçilik ve Şanlıurfa Aşiretleri Tarihi. Ankara: İmaj Yayıncılık.

Brunet-Jailly, E. \& Dupeyron, B. (2007). "Introduction: Borders, Borderlands, And Porosity", İ Borderlands: Comparing Border Security in North America and Europe, ed. Emmanuel Brunet-Jailly. Ottawa: University of Ottawa Press.

Carpiano, R. M.(2006). "Toward A Neighborhood Resource-Based Theory of Social Capital for Health: Can Bourdieu and Sociology Help?" Social Science and Medicine, 62/1: 165-175.

Coleman, J. (1990). Foundations of Social Theory. Cambridge, Mass: Belknap Press of Harvard University Press.

Crisp. J. (1999). Policy Challenges of the New Diasporas: Migrant Networks and Their Impact On Asylum Flows and Regimes. Geneva: UNHCR.

Çelikkol, O. (2015). içimizdeki Komşu. Ankara: Bilgesam Yayınları.

Çetin, S. (2017). “Izmir'deki Yerel Halkın Suriyeli Mültecilere Yönelik Algısı” (II. Gerçek ve Umut Arasında Suriyeli Mülteciler Sempozyumu, Adıyaman Üniversitesi, 20-22 Ekim.

Dalar, M. (2016). “Birleșmiş Milletler Güvenlik Konseyi'nin Suriye Krizindeki Tutumu”, Suriye: Çatışma ve Uluslararası Hukuk, ed. Fatma Taşdemir. Ankara: Nobel Akademik Yayıncilık.

Danış, A. D. (2010). İstanbul'daki Iraklı Göçmenlerin Parçalı Eklemlenme Sürecinde Toplumsal Ağlar, "Türkiye’ye Uluslararası Göç: Toplumsal Koşullar, Bireysel Yaşamlar” In, eds. Barbara Pusch, Tomas Wilkoszewski, Çev. Mutlu Çomak Özbatır.İstanbul: Kitap Yayınevi: 191-224.

Durkheim, E. (2018). The Division of Labor in Society, "Inequality”, In eds. David B. Grusky \&Szonja Szelényi. Londra: Routledge.

Eriksen, T. H. (2002). Ethnicity and Nationalism: Anthropological Perspectives. Pluto Press.

Fenton, S. (1999). Ethnicity: Modernity, Racism, Class And Culture, Macmıllan Press.

Halbwachs, M. (1992). On Collective Memory. Univ. of Chicago Press. 
Kaya, M. (2004). "Güneydoğu Anadolu Bölgesinde Çok Eşlilik Olgusu (Şanlıurfa Örneği).” yüksek lisans tezi, Harran Üniversitesi, 2004.

İnce, C. (2018). "Spatial Sociology of Immigration: The Example of Şanlıurfa." doctoral dissertation, Anatolian University, 2018.

İnce, C. (2019). "An Evaluation On Migration Theories and Syrian Migration." OPUS International Journal of Society Researches, 11(18): 2579-2615.

Kaya, M. (2015). "Komşuda Misafirlik: Suriyeli Sığınmacılarca Kurulmuş Mülteci Derneklerinin Perspektifinden Türkiye'de Yaşamak." International Journal of Social Science, 39: 263-279.

Kaya, M. (2017). Türkiye'deki Suriyeliler iç içe Geçişler ve Karşılaşmalar. İstanbul: Hiperlink Yayınları.

Kaynak, S., et al. (2016). "Göçün Sosyo-Ekonomik Sonuçları: Suriyeli Göçmenler Üzerine Bir Uygulama.” 2. Uluslararası Uygulamalı Bilimler Kongresi: Göç, Yoksulluk ve İstihdam, Necmettin Erbakan Üniversitesi Uygulamalı Bilimler Yüksek Okulu, Konya, 23-25 Eylül.

Keser, ì. (2008). Kent Cemaat Etnisite: Adana ve Adana Nusayrileri Örneğinde Kamusallık. Ankara: Ütopya Yayınevi.

Khaldun, I. (2004). Mukaddime, Çev. Halil Kendir. Ankara: Yeni Şafak.

Kurtoğlu, M. (2016). Bu Eller Utandırmaz Adamı: Göçler, Mülteciler ve Suriye Savaşı. Konya, Çizgi Kitapevi.

Leach, J. (2003). Creative Land: Place and Procreation on The Rai Coast of Papua New Guinea. New York, Berghahn.

Mcdowall, D. (1996). The Kurds 4. Minority Rights Group International.

Murdie, R. A., \& Borgegård, L. (1998). "Immigration, Spatial Segregation and Housing Segmentation of Immigrants in Metropolitan Stockholm, 1960-95." Urban Studies, 35/10: 1869-1888.

Öğüt, T. (2011). "Milli Sınırların Oluşumu Sürecinde Güneydoğu Anadolu'da Kaçakçılık Ekonomisi.” iktisadi ve Idari Bilimler Dergisi 31/2: 91-122.

Ökten, Ş. (2006). "GAP Bölgesi'nin Sosyo-Kültürel ve Yapısal Özelliklerinin Aile Yapısına Etkileri." Aile ve Toplum 3/9: 23-34.

Ökten, Ş. (2009). "Aşiret, Akrabalık ve Sosyal Dayanışma: Geleneksel Hayatı Yönetme Biçimi." Sosyal Politika Çalışmaları Dergisi 18/18: 99-112.

Özgen, N. (2005). "Sınır Kimliği; Sınırlar ve Egemenlik" (I. Ulusal Sosyal Bilimler Kongresi, TSBD, ODTÜ, Ankara, 7-9 Aralık).

Palloni, A., et al., (2001). "Social Capital And International Migration: A Test Using Information On Family Networks." American Journal of Sociology 106/5: 12621298.

Sahlins, M. (2013). What Kinship Is-And Is Not. University of Chicago Press.

Simpson, S. (2017). "Spatial Patterns of International Migrant Resident Settlement And incorporation In Winnipeg Manitoba." Population, Space and Place 23.

Stasch, R. (2009). Society of Others: Kinship and Mourning in A West Papuan Place. University of California Press. 
Şenoğuz, H. P. (2014). "Demarcating Kilis as A Border Town: Community, Belonging And Social Mobility Among Socio-Economic Strata On The Syrian Border Of Turkey." (doctoral dissertation, Mıddle East Technıcal Unıversıty). Taştan, Y. K. (2010). "Etnisite Kuramları." Siyaset ve Kültür Dergisi, 6: 199-228.

Van Kempen, R., \& Özüekren, A. Ş. (1998). "Ethnic Segregation in Cities: New Forms and Explanations in A Dynamic World." Urban Studies 35/10: 16311656. 